\title{
A new record of Ixodes pavlovskyi Pomerantzev from Hokkaido, Japan (Acari: Ixodidae)
}

\author{
Minoru Nakao, ${ }^{*}$ Kenji Miyamoto* and Shigeo Kitaoka** \\ * Department of Parasitology, Asahikawa Medical College, Asahikawa 078, Japan \\ ** Niigata Sangyo University, Kashiwazaki 945-13, Japan
}

(Received: February 27, 1992)

Key words: Ixodidae, Ixodes pavlovskyi, Hokkaido, new record.

\begin{abstract}
The ixodid tick species closely related with Ixodes persulcatus and I. nipponensis is recorded from Hokkaido, Japan, for the first time. The fieldcollected unfed adults and the laboratory-reared immatures are identified as $I$. pavlovskyi Pomerantzev that is new to Japan.
\end{abstract}

Ixodes pavlovskyi Pomerantzev (Acari: Ixodidae) is distributed in the Palearctic region, particularly the Far East and East Siberia (Filippova, 1985a), and until recently this species was unknown from Japan. The authors collected males and females of $I$. pavlovskyi by flagging vegetation in the forests of following localities of Hokkaido. This is the first record of $I$. pavlovskyi from Japan.

Two males and 7 females, May 17, 1990, Iwaonai $\left(44^{\circ} 08^{\prime} \mathrm{N}, 142^{\circ} 44^{\prime} \mathrm{E}\right)$; 1 female, May 6 , 1991, Jozankei $\left(42^{\circ} 58^{\prime} \mathrm{N}, 141^{\circ} 09^{\prime} \mathrm{E}\right) ; 6$ males and 10 females, May 11, 1991, Iwaonai; 13 males and 21 females, May 20, 1991, Iwaonai; and 2 males and 2 females, May 26, 1991, Asahikawa $\left(43^{\circ} 43^{\prime} \mathrm{N}, 142^{\circ} 21^{\prime} \mathrm{E}\right)$. At these localities, many adults of Ixodes persulcatus Schulze and Ixodes ovatus Neumann were also collected.

To obtain the immature stages of Japanese I. pavlovskyi, 4 females from Iwaonai were fed on ears of a rabbit for 6-8 days. Each engorged female was placed in a $60 \times 30 \times 15$ $\mathrm{mm}$ plastic box individually, and maintained at $25^{\circ} \mathrm{C}$ in a saturated humidity with $12 \mathrm{hr}$ of light per day. The preoviposition, ovi-

* 中尾 稔, 宮本健司: 旭川医科大学寄生虫学教室 (干078 旭川市西神楽 4 線 5号 3-11)

** 北岡茂男: 新潟産業大学 (干945-13 柏崎市軽井 川 4730) position and egg periods were 8-10, 14-28 and 26-36 days, respectively. The larvae were fed on mice for 3-5 days, and reared under the same condition as described above. The engorged larvae molted into nymphs within 18-30 days. The morphologic characters of larvae and nymphs from Hokkaido well accorded with the descriptions of Russian specimens of I. pavlovskyi (Filippova, 1985b).

\section{Ixodes pavlovskyi Pomerantzev}

Ixodes pavlovskyi Pomerantzev, 1948, Parazitol. Sbornik, Zool. Inst. Akad. Nauk SSSR 9: 39-46.

Specimens were examined by standard light, phase contrast, and scanning electron (Nihon Denshi, JSM T200) microscopes. All measurements are in $\mathrm{mm}$. Specimens examined were as follows: 6 males from Iwaonai, 1 male from Asahikawa, 4 females from Iwaonai, 2 females from Asahikawa, 1 female from Jozankei, 10 laboratory-reared nymphs, 10 laboratory-reared larvae. Body chaetotaxy of larvae was submitted to the description by Clifford and Anastos (1960).

Male (Figs. 1, 2, 9, 10, 17, 18, 24). Legs and body excluding scutum and coxae pale brown (live specimen). Idiosomal length 


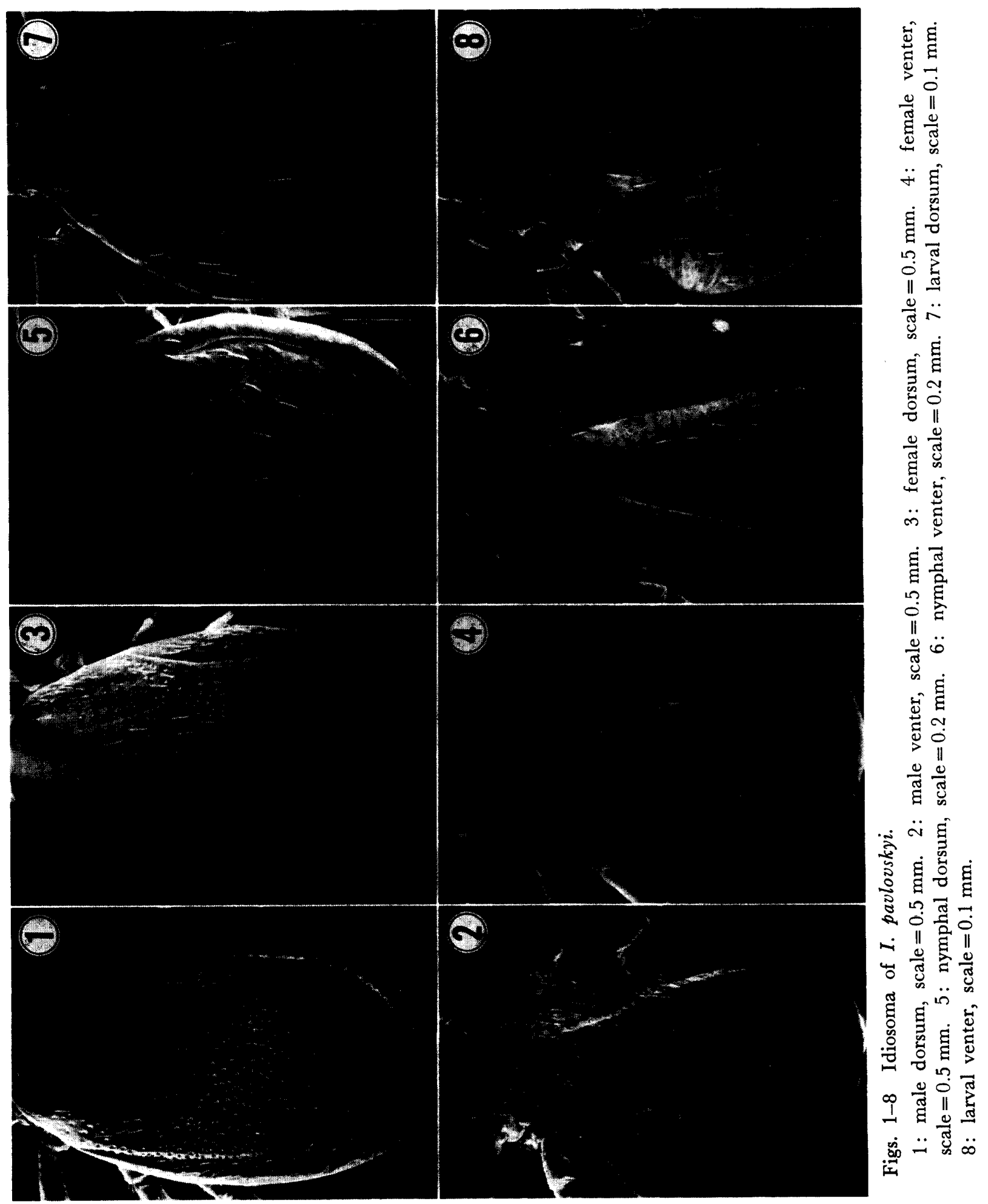









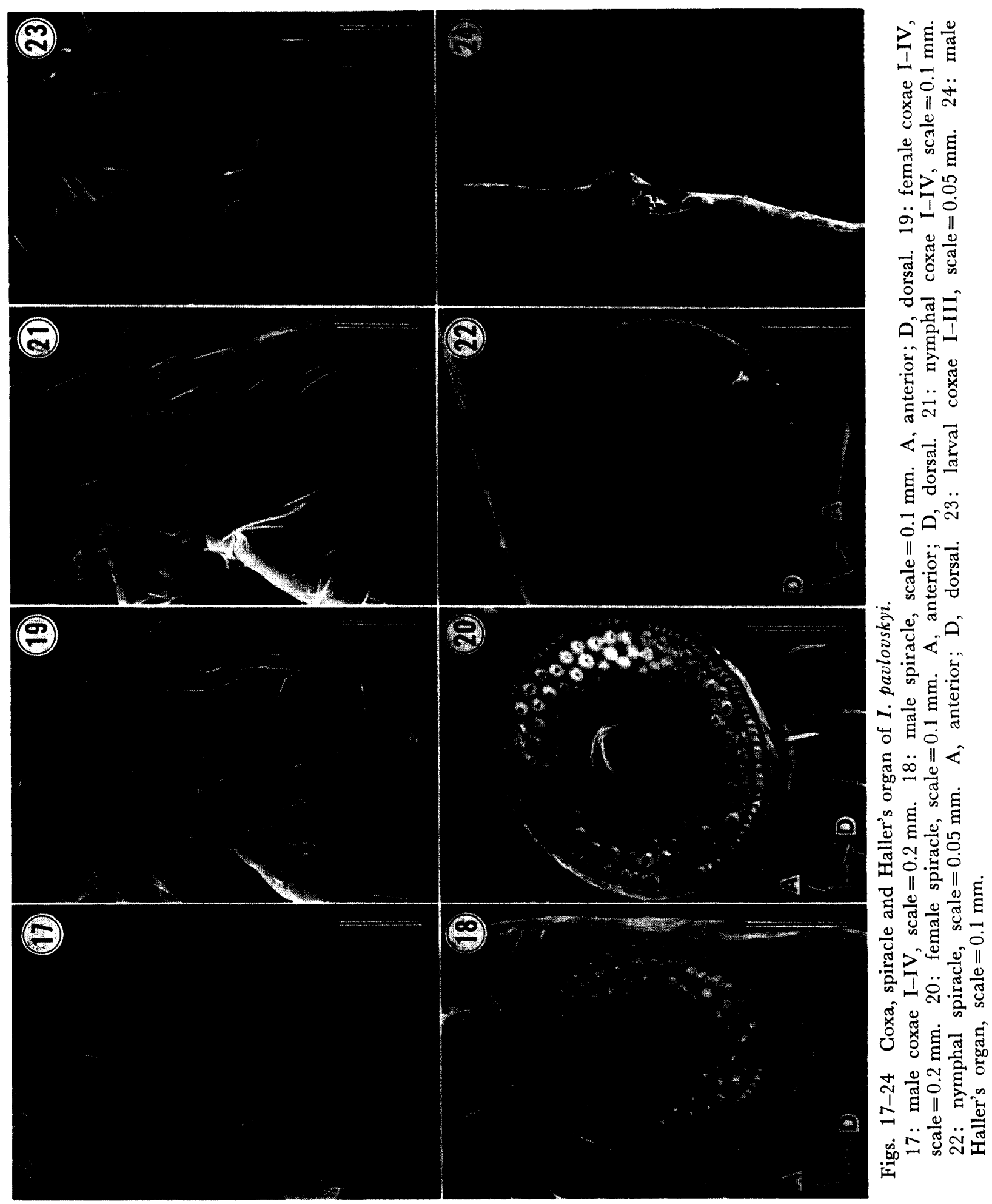


2.1-2.4, width 1.3-1.5. Length from palpal apices to posterior margin of basis capituli $0.54-0.57$. Basis capituli $0.30-0.32$ wide dorsally; tiny cornua present (Fig. 9). Palpi 0.43-0.45 long, 0.15-0.17 wide. Hypostome $0.25-0.26$ long, dentation as in Fig. 10. Coxae I-IV each with a distinct external spur; coxa I with a short internal spur reaching to anterior margin of coxa II (Fig. 17). Legs I-IV with lengthy segments; largest length 0.70-0.79 (tarsus I). Haller's organ anteriorly with 2 lengthy setae of $0.15-0.21$ long (Fig. 24). Genital aperture between coxae III. Spiracular plates subcircular; greatest diameter 0.30-0.32 (Fig. 18).

Female (Figs. 3, 4, 11, 12, 19, 20). Legs and body excluding scutum and coxae pale brown (live specimen). Idiosomal length 2.4-2.6, width 1.6-1.7. Scutum 1.4-1.5 long, 1.1-1.2 wide; outline elliptical (Fig. 3). Length from palpal apices to cornua apices 0.78-0.86. Basis capituli (0.51-0.57 wide dorsally. Palpi 0.66-0.76 long, 0.19-0.21 wide. Hypostome acute at apex, 0.47-0.50 long; dental formula 4/4, 3/3,2/2 (Fig. 12). Coxae I-IV each with a distinct external spur; coxa I with a long internal spur reaching to anterior $1 / 3$ of coxa II (Fig. 19). Genital aperture between coxae IV. Spiracular plates subcircular; greatest diameter 0.270.35 (Fig. 20).

Nymph (Figs. 5, 6, 13, 14, 21, 22). Idiosomal length 1.2-1.3, width 0.8-0.9. Scutum $0.60-0.63$ long, 0.58-0.63 wide. Scutal setae considerably shorter than postscutal ones (Fig. 5). Length from palpal apices to cornua apices 0.37-0.39. Basis capituli 0.24-0.25 wide dorsally. Palpi 0.32-0.33 long, 0.080.09 wide. Hypostome $0.20-0.22$ long; dental formula $3 / 3,2 / 2$ (Fig. 14). Coxae I-IV each with a distinct external spur; coxa I with an internal spur reaching to anterior margin of coxa II (Fig. 21). Spiracular plates circular; diameter 0.16-0.17 (Fig. 22).

Larva (Figs. 7, 8, 15, 16, 23). Body excluding capitulum $0.58-0.60$ long, $0.48-0.49$ wide. Scutum $0.33-0.35$ long, $0.35-0.37$ wide. Length from palpal apices to posterior margin of basis capituli 0.19-0.20. Basis capituli 0.14-0.15 wide dorsally; cornua extended laterally (Fig. 15). Palpi 0.17-0.18 long, 0.04 wide. Hypostome 0.10-0.11 long; dental formula $3 / 3,2 / 2$ (Fig. 16). Body chaetotaxy
(Figs. 7, 8); 5 scutal pairs $\left(\mathrm{Sc}_{1}-\mathrm{Sc}_{5}\right)$ and 12 postscutal pairs $\left(\mathrm{Md}_{1}-\mathrm{Md}_{7}, \mathrm{Cd}_{1}-\mathrm{Cd}_{4}, \mathrm{~S}_{1}\right)$ on dorsum; 13 pairs $\left(\mathrm{St}_{1}-\mathrm{St}_{3}, \mathrm{Pm}_{1}-\mathrm{Pm}_{4}\right.$, $\left.\mathrm{Mv}_{1}-\mathrm{Mv}_{\mathbf{4}}, \mathrm{Pa}_{1}-\mathrm{Pa}_{2}\right)$ on venter and 1 anal pair (A). Scutal setae shorter than postscutal ones (Fig. 7); $\mathrm{Sc}_{3}$ 0.022-0.027 long, $\mathrm{Cd}_{1}$ 0.034-0.045 long. Length of ventral setae, $\mathrm{St}_{1}$ 0.049-0.057, $\mathrm{Pa}_{1}$ 0.032-0.040. External spurs of coxae I and II distinctly longer than that of coxa III; coxa I with a long and acute internal spur reaching to anterior margin of coxa II (Fig. 23).

Host. In eastern Kazakhstan, the adults of $I$. pavlovskyi were found on birds, mainly Turdus pilaris, and its immatures were detected from many species of rodents and birds (Filippova and Ushakova, 1967; Ushakova and Filippova, 1968). In Japan, the authors collected the immature stages of $I$. pavlovskyi from the following rodents captured in Asahikawa: 4 larvae from 4 Apodemus speciosus ainu, June 26, 1991; 17 larvae and 2 nymphs from 1 Rattus norvegicus, June 26, 1991.

\section{Key to the species closely related with I. pavlovskyi in Hokkaido}

In Hokkaido, I. persulcatus and Ixodes nipponensis Kitaoka et Saito are the species closely related with $I$. pavlovskyi. Key to the adult and immature ticks of these 3 species are as follows:

Males

1. Internal spur of coxa I long and acute, reaching to anterior $1 / 4-1 / 3$ of coxa II $\ldots \ldots \ldots \ldots \ldots \ldots$ I. persulcatus Internal spur of coxa I short, reaching to anterior margin of coxa II ........ 2

2. Spiracular plate oval; legs blackish brown, not distinctly longer than idiosoma .... ................ nipponensis Spiracular plate subcircular; legs pale brown, distinctly longer than idiosoma .. ................... I. pavlovskyi

\section{Females}

1. Internal spur of coxa I short, reaching to anterior margin of coxa II .......... I. nipponensis 
Internal spur of coxa I long and acute, reaching to anterior $1 / 3-1 / 2$ of coxa II

2. External spur of coxa IV tiny; hypostome round at apex; legs blackish brown, postscutal idiosoma dark reddish brown .... $\ldots \ldots \ldots \ldots \ldots \ldots$. . persulcatus External spurs of coxae I-IV distinctly long; hypostome acute at apex; legs and postscutal idiosoma pale brown .......

I. pavlouskyi

Nymphs

1. Hypostome sharply pointed at apex .... $\ldots \ldots \ldots \ldots \ldots \ldots$ I. nipponensis Hypostome round at apex ........ 2

2. External spur of coxa IV considerably shorter than those of coxae I-III; scutal and postscutal setae almost equal in length to one another ....I. persulcatus External spurs of coxae I-IV long and subequal in length to one another; scutal setae shorter than postscutal ones ...... ................. I. pavlovskyi

Larvae

1. Scutal and postscutal setae almost equal in length to one another ... I. persulcatus Scutal setae shorter than postscutal ones $\ldots \ldots \ldots \ldots \ldots \ldots \ldots \ldots \ldots$

2. External spurs of coxae I-III short and subequal in length to one another; internal spur of coxa I short, not reaching to anterior margin of coxa II ........ $\ldots \ldots \ldots \ldots \ldots$ I. nipponensis External spurs of coxae I and II distinctly longer than that of coxa III; internal spur of coxa I long and acute, reaching to anterior margin of coxa II ........ ................ I. pavlovskyi

\section{Acknowledgements}

The authors are grateful to Dr. Nobuhiro Takada, Department of Immunology and Parasitology, Fukui Medical School for valuable suggestions on identifying the species. Thanks are also due to Dr. N. A. Filippova, Zoological Institute, Academy of Sciences of the Russia for supplying the speci- mens of all stages of I. pavlovskyi from Kazakhstan, and to Mr. Kiyoshi Miyakawa, Gentral Laboratory for Medical Research, Asahikawa Medical College for his technical advice on scanning electron microscopy.

\section{REFERENGES}

Clifford, C. M. and G. Anastos (1960): The use of chaetotaxy in the identification of larval ticks (Acarina: Ixodidae). J. Parasitol., 46: 567578.

Filippova, N. A. (1985a): Distribution of species of the persulcatus group and palaeogenesis of the taiga tick area. In: Taiga Tick, Ixodes persulcatus Schulze (ed., Filippova, N. A.), pp. 204-212, Nauka Publishers, Leningrad (in Russian).

Filippova, N. A. (1985b): Diagnoses of species of the persulcatus group. In: Taiga Tick, Ixodes persulcatus Schulze (ed., Filippova, N. A.), pp. 107-173, Nauka Publishers, Leningrad (in Russian).

Filippova, N. A. and G. V. Ushakova (1967): On the species of the group Ixodes persulcatus (Ixodidae, Parasitiformes). I. I. pavlovskyi Pom. in eastern Kazakhstan; Redescription of female and description of male. Parazitologiia, 1: 269-278 (in Russian).

Pomerantzev, B. I. (1948): New species of Ixodes (Ixodoidea). Parazitol. Sbornik, Zool. Inst. Akad. Nauk SSSR, 9: 39-46 (in Russian).

Ushakova, G. V. and N. A. Filippova (1968): On the species of the Ixodes persulcatus group (Parasitiformes, Ixodidae). II. On the ecology of I. pavlovskyi from east Kazakhstan. Parazitologiia, 2: 334-338 (in Russian).

\section{摘 要}

日本新記録の Ixodes pavlovskyi Pomerantzev

$$
\text { (ダニ目，マダ二科） }
$$

北海道朝日町岩尾内，旭川市上雨粉，札幌市定山渓 の森林でハタズリ法により植生上から末吸血のマダニ 類を採集したところ，シュルツェマダニやタネガタマ ダニに類似した雌雄成虫を発見した. これらの成虫と 実験室内飼育で得た幼若虫はシベリア大陸に分布する Ixodes pavlovskyi Pomerantzev，1948 と形態が一致 したため，北海道からの新記録として報告した。北海 道ではライム病が確認されたことにより，その媒介種 であるシュルツェマダニを 正確に 同定する必要があ る.I. pavlovskyi は検索表に示した特徴で, 類似種の シュルツェマダニとタネガタマダニから区別できる. 